\title{
ВОВЛЕЧЕНИЕ ОБЩЕСТВЕННОСТИ КАК ОДИН ИЗ НАИБОЛЕЕ ЭФФЕКТИВНЫХ ИНСТРУМЕНТОВ ПРЕДОТВРАЩЕНИЯ КОНФЛИКТА ИНТЕРЕСОВ В ГОСУДАРСТВЕННОМ СЕКТОРЕ SOCIETY INVOLVEMENT AS ONE OF THE MOST EFFECTIVE TOOLS TO PREVENT CONFLICTS OF INTEREST IN THE PUBLIC SECTOR
}

\author{
Ярослав Стрельченок \\ доцент и докторант Университета Туриба (Латвия) \\ начальник Бюро по предотвращению и борьбе с коррупцией Латвии (2011-2016) \\ jaroslavs.strelcenoks@gmail.com
}

\begin{abstract}
:
The problem of corruption is one of the most pressing in the world. Corruption increases distrust of officials and the state. It contributes to the creation of a disrespectful attitude towards regulations. Active work is underway throughout the world to prevent corruption and conflict of interest. The author offers one of the most effective tools to solve this problem - the active involvement of the public in public administration processes. This tool can significantly reduce the risks of corruption and conflict of interest.

Based on the practice of Latvia in involving the public in public administration processes, the author carries out a comparative analysis of the involvement of society in anticorruption processes: in the right to receive information, in the right to exercise public control over the property status of officials, in the right of participation of public organizations in the activities of various ministries and departments. The author analyses the international assessments of Latvia in the perception of corruption and reveals a pattern. States that promote the involvement and active participation of society in public sector processes carry out the most effective activities to prevent conflicts of interest of public officials. Thus, the author, using general scientific as well as special methods of legal knowledge: analysis and synthesis methods, scientific induction method, deduction method and comparative method, proves his hypothesis that society involvement is one of the most effective tools to prevent conflicts of interest in the public sector.
\end{abstract}

Ключевые слова: гражданское общество, конфликт интересов, предотвращение коррупщии, государственный сектор 


\section{Введение}

Традиционно для борьбы с коррупцией государства создают специализированные антикоррупционные комиссии и учреждения, принимают антикоррупционные законы и устанавливают ответственность за коррупционные деяния. Сегодня проблема коррупции является одной из самых острых в мире ${ }^{1}$. Коррупция стала самой большой проблемой для самого общества. Существование коррупции увеличивает недоверие к должностным лицам и государству в целом, а также способствует созданию неуважительного отношения к нормативным актам. Коррупция является самым большим препятствием на пути экономического роста и развития любой страны.

В настоящее время во всём мире, а также в странах Европейского Союза (в том числе и в Латвии) ведётся активная работа по предупреждению коррупции и конфликта интересов. Однако применение со стороны государства перечисленных методов по предотвращению коррупции и конфликта интересов зачастую недостаточно эффективно. Повышение ответственности должностных лиц также не всегда беспокоит правонарушителей и является проблемой для них. В связи с этим, предлагается один из наиболее эффективных инструментов решения этой проблемы - активное вовлечение общественности в процессы государственного управления. Данный инструмент способен значительно снизить риски коррупции и конфликта интересов в государственных и муниципальных учреждениях. Вовлечение общественности может существенно предотвратить использование должностными лицами своего положения, статуса и власти, а также получение личных и имущественных выгод для себя, своих родственников и деловых партнёров.

Автор намерен на основе практики Латвии по вовлечению общественности в процессы государственного управления, а именно в праве на получение информации, вправе осуществления общественного контроляза имущественным состоянием должностных лиц, в праве участия общественных организаций в деятельности разных министерств и ведомств, осуществить сравнительный анализ вовлечения общества в вопросы предотвращения коррупции и конфликта интересов. На основании данного анализа автор планирует проанализировать международные оценки Латвии в восприятии коррупции и выявить закономерность того, что государство, способствующие вовлечению и активному участию общества в процессах государственного сектора, осуществляют наиболее эффективную деятельность по предотвращению конфликта интересов среди должностных лиц. Таким образом автор стремится доказать свою гипотезу, что вовлечение общественности является одним из наиболее эффективных инструментов предотвращения конфликта интересов в государственном секторе.

1 (Новости ООН, 2018) 
Автор ставит перед собой следующие задачи для достижения цели:

1) изучить международную практику вовлечение общества в предотвращение конфликта интересов;

2) проанализироватьопыт Латвии пововлечениюобществавпредотвращение коррупции;

3) на примере Латвии определить права и сферы вовлечения общества, в которых общественный контроль был бы наиболее целесообразным, чтобы избежать ситуаций конфликта интересов;

4) установить взаимосвязь степени вовлечения общества с международными и национальными результатами предотвращения коррупции, а также дать оценку прогнозов изменений (снижения или увеличения) коррупционных рисков в системах государственного управления после внедрения общественного контроля в государственные процессы.

\section{1. Международная практика вовлечения общества в антикорупционную деятельность}

Значимость общества в предотвращении коррупции и конфликта интересов отмечена в разных международных документах.

В соответствии с международным регулированием каждое государство должно стремится, в соответствии с основополагающими принципами своего внутреннего законодательства, создавать, поддерживать и укреплять системы, которые способствуют прозрачности и предупреждают возникновение коллизии интересов ${ }^{2}$.

Международные документы предлагают также различные инструменты ${ }^{3}$ предотвращения и регулирования конфликта интересов наделяя общество следующими правами:

1) на получение информации;

2) осуществлять общественный контроль за имущественным состоянием должностных лиц;

3) участвовать в деятельности государственных органов;

4) осуществлять контроль за фактами неправомерного использования государственного имущества и ресурсов в частных интересах и др. ${ }^{4}$

В разных странах существуют различные способы, позволяющие выявить личные интересы должностного лица, вступающие в конфликт с интересами его службы. Основной источник такой информации - само должностное лицо. Однако немало таких стран, где важным источником такой информации

\footnotetext{
2 (Конвенция Организации Объединенных Наций против коррупции, 2003)

3 (Международный кодекс поведения государственных должностных лиц, 1996)

${ }^{4}$ (OECD, 2005)
} 
выступает общество. ${ }^{5}$

Таблица №1

\begin{tabular}{|c|c|c|}
\hline \multirow{2}{*}{ Страна } & \multicolumn{2}{|c|}{ Раскрытие данных деклараций } \\
\cline { 2 - 3 } & публичные & закрытые \\
\hline Азербайджан & & $\mathrm{X}$ \\
\hline Беларусь & & $\mathrm{X}$ \\
\hline Казахстан & & $\mathrm{X}$ \\
\hline Кыргызстан & & $\mathrm{X}$ \\
\hline Латвия & $\mathrm{X}$ & \\
\hline Литва & $\mathrm{X}$ & \\
\hline Таджикистап & & $\mathrm{X}$ \\
\hline Франшия & $\mathrm{X}$ & \\
\hline Финляндия & $\mathrm{X}$ & \\
\hline Норвегия & $\mathrm{X}$ & \\
\hline Эстония & $\mathrm{X}$ & \\
\hline
\end{tabular}

Например, в Финляндии государственная политика профилактики и пресечения конфликта интересов отражена в государственной Программе по борьбе с преступлениями в экономической сфере ${ }^{6}$. Однако самый главный фактор предотвращение конфликта интересов - это общественный надзор. Согласно которому все решения властей необходимо обосновать, в т.ч. публично. Каждый, кто недоволен полученным решением, имеет право обжаловать это решение. Также под общественным надзором находится профессиональная деятельность всех должностных лиц. Сама деятельность органов власти в основном осуществляется публично. СМИ и даже отдельным гражданам доступны сведения, получаемые из различных регистров. Должностные лица обязаны периодически представлять декларации о своих доходах и их источниках, которые предаются публичной огласке. Благодаря этому ситуации по подозрению в нахождении должностного лица в конфликте интересов достаточно легко выявлять и давать им правовую оценку.

Во Франции созданы правовые и организационные основы, обеспечивающие широкую гласность деклараций о доходах и имуществе высокопоставленных должностных лиц.

В Норвегии сведения об общих доходах и уровне благосостояния должностных лиц размещены в интернете и доступны для открытого поиска и ознакомления. ${ }^{7}$

Полное публичное раскрытие, т.е. вся информация, содержащаяся в декларациях, доступна для общественного контроля в Дании ${ }^{8}$, Латвии и Эстонии (см. Таблицу №1).

5 (Юридический консультант, 2009)

6 (Охотский Е., 2018)

7 (ОЭСР, 2011)

8 Там же 
Международных стандартов, требующих обеспечение публичного раскрытия декларируемой информации в обязательном порядке, не существует. Поэтому в некоторых странах публичное раскрытие декларации нередко ограничено опубликованием обобщённых данных, придерживаясь принципа конфиденциальности. Такой путь публичности деклараций выбрали Беларусь, Кыргызстан, Казахстан и Таджикистан. ${ }^{9}$

Например, в Казахстане доступ к декларации может предоставляться в целях расследования налоговых нарушений и только по запросам правоохранительных органов и судов. К примеру в Кыргызстане доступ к декларации также может предоставляться правоохранительным органам только в ходе уголовных расследований. ${ }^{10}$

\section{2. Практика Латвии вовлечения общества в выявление конфликта интересов}

2.1. Международная и национальная антикоррупционная оценка Латвии

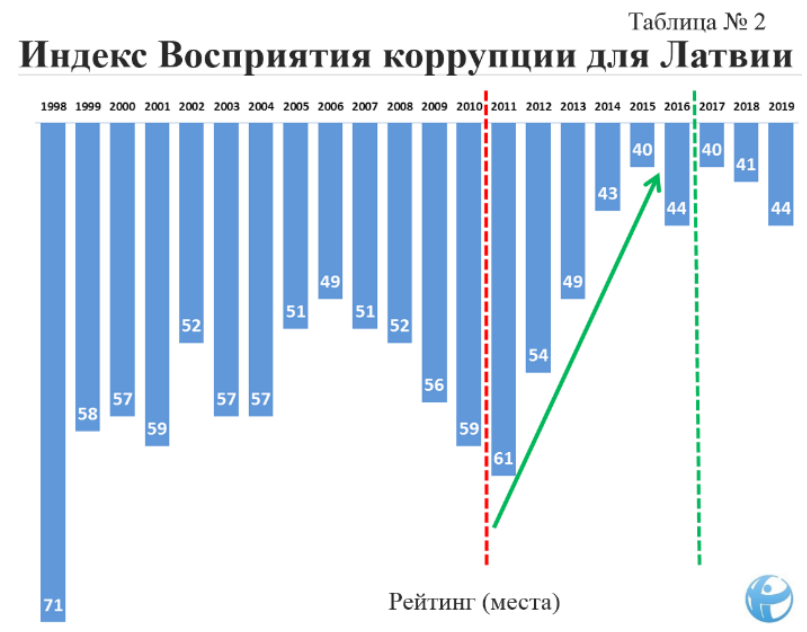

На протяжении более чем 20 лет международная антикоррупционная организация Transparency International публикует индекс восприятия коррупции. ${ }^{11}$ В 1998 году Латвия впервые получила в данном индексе своё 71 место с 27-ю пунктами. Это был самый низкий результат для страны. Затем были 9 Там же

10 (ОЭСР, 2018)

11 Индекс восприятия коррупции ежегодно публикует международная антикоррупционная организация Transparency International. Этот рейтинг является наиболее используемым индикатором уровня коррупции в публичном секторе и основывается на результатах 13 различных исследований. В индексе используется шкала от 0 о 100, где 0 свидетельствует о высоком уровне восприятия коррупции, а 100, наоборот, о низком. 
улучшения показателей индекса, а также его падения. В 2019 году в Индексе восприятия коррупции Латвия набрала 56 пунктов из 100, расположившись на 44-й строчке рейтинга из 180 стран, что на два пункта меньше, чем в 2018 году (см. Таблицу № 2).

Анализ данных, из которых складываются результат, показал, что в 2019 году снизилась оценка борьбы с политической коррупцией в Латвии, в том числе в таких формах, как конфликт интересов и влияние частного сектора на государственное управление, чтобы получить преимущество ${ }^{12}$.

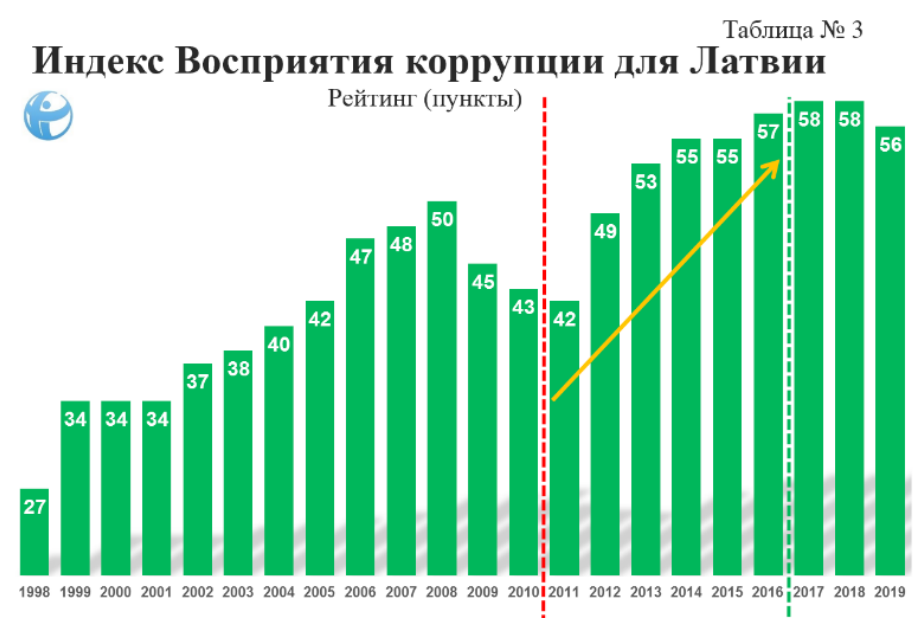

Позиции Латвии в глобальном индексе восприятия коррупции Transparency International стагнируют уже много лет, потому что страна безуспешно борется с коррупцией, заявила директор «Общества за открытость Delna». Глава Delna убеждена, что для улучшения позиций Латвии в рейтинге Transparency International нужно больше работать в направлении предотвращения преступлений и просвещения общества для «снижения терпимости к коррупции». ${ }^{13}$

\footnotetext{
12 (Baltic News Network, 2020)

13 (Редакция Латвийского общественного СМИ, 2020)
} 
Таблица № 5

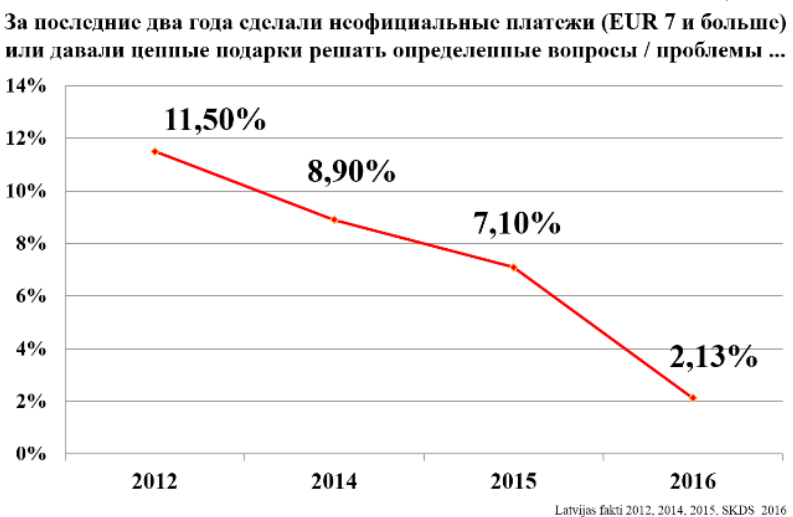

Однако автор отмечает, что позиции Латвии в глобальном индексе восприятия коррупции Transparency International в период времени с 2011 года по 2016 год стремительно улучшались и были значительно выше чем в период отмеченный главой Delna. Латвия за пять лет с 2011 по 2016 год с 61 поднялась на 40 место, улучшив свою позицию в рейтинге на 21 место. Соответственно за тот же период с 42 пунктов в 2011 году за пять лет в 2016 году набрала 57 пунктов, что соответствует приросту в 15 пунктов (см. Таблицу № 3).

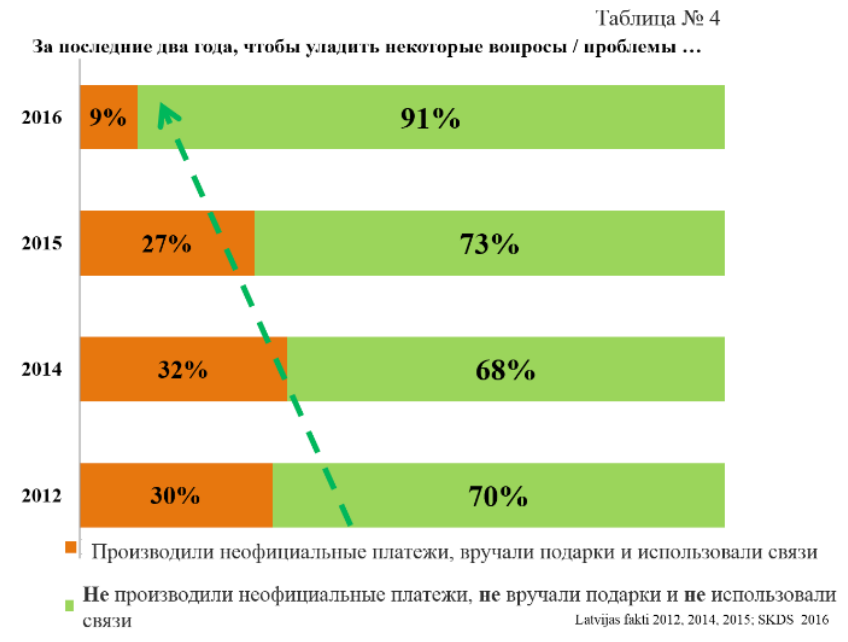

Данные международной антикоррупционной организации Transparency International подтверждаются и внутренними социологическими опросами, проведёнными в период времени с 2012 года по 2016 год. (см. Таблицу № 4) Согласно опросам населения Латвии в упомянутый период времени, среди опрошенных респондентов значительно уменьшилось (с 30\% до 9\%) количество 
тех, кто производил неофициальные платежи, вручал подарки и использовал связи, чтобы уладить некоторые вопросы или проблемы в государственных органах с должностными лицами. Более того в данный период времени также уменьшилось (с $12 \%$ до 2\%) количество тех, кто решал проблемы с помощью подкупа должностных лиц (см. Таблицу № 5).

Возникает вопрос, что способствовало столь стремительному уменьшению коррупционных рисков и улучшению международного рейтинга Латвии.

Анализируя реализуемую антикоррупционную политику Латвии и деятельность антикоррупционного бюро Латвии ${ }^{14}$ в период времени с 2011 по 2016 год, а также сравнивая её до и после данного периода времени, можно сделать предположение, что на практике в данный период времени использовались разные средства и методы предотвращения коррупции и конфликта интересов, в т.ч. активное вовлечения общества.

\section{2. Практика вовлечения общества в выявление конфликта интересов}

Для наиболее эффективного выявления и решения конфликта интересов государство гражданскому обществу может предоставить определённые инструменты, среди которых публичная система декларирования, право на получение информации, возможность осуществлять гражданский контроль и др. Иногда обществу предоставляется отдельные инструменты, а иногда совокупный комплекс таких инструментов. Реализуемая антикоррупционная политика и деятельность антикоррупционного бюро Латвии в период времени с 2011 по 2016 год не только предоставила обществу такие инструменты, но и активно их популяризировала с целью вовлечь по возможности все группы общества в предотвращение коррупции и конфликта интересов в государственном секторе.

\subsection{1. Система декларирования}

В целях выявления конфликта интересов на должностных лиц Латвии возложен ряд обязанностей, в частности предоставление декларации о своём имущественном и финансовом состоянии. Данные сведения о доходах, имуществе и обязательствах имущественного характера публичные и на их основании возможно осуществлять антикоррупционный мониторинг должностного лица.

Предоставляя данные сведения обществу, а также разного уровня (национального и регионального) и формата (печатные, аудио или аудиовизуальные) средствам массовой информации (СМИ), Латвия уменьшила финансовое бремя на анализ поступающих сведений. На основании результатов общественного мониторинга, в результате которого выявляются признаки

14 Бюро по предотвращению и борьбе с коррупцией Латвии (латыш. - Korupcijas novēršanas un apkarošanas birojs или сокращённо - KNAB) 
коррупционных рисков возникновения конфликта интересов у должностных лиц, компетентные государственные органы осуществляют проверку.

Таким образом, механизм выявления и разрешения конфликта интересов в Латвии происходит путём огласки данных декларации должностного лица.

Поэтому система декларирования в Латвии имеет общедоступный характер, что подразумевает под собой публикацию деклараций должностных лиц в Интернете на едином портале Службы государственных доходов Латвии. Такой подход упрощает работу с декларациями и доступ к ним гражданам страны.

Также для усовершенствования механизмов урегулирования конфликта интересов в органах власти стараются повысить уровень информационной открытости и эффективности работы должностных лиц, что подразумевает свободный доступ к информации об их деятельности и получаемых ежемесячно доходах в учреждении со стороны граждан и общественных организаций, посредством размещения соответствующих сведений на официальном сайте каждого государственного учреждения.

\subsection{2. Гражданский контроль}

Особую роль при изучении и разработке механизмов урегулирования конфликта интересов играет гражданский контроль.

Гражданскийконтрольможетвлиятьнаегопредупреждениеирегулирование определёнными способами. Изначально стоит понять, на что именно может повлиять гражданский контроль для предотвращения и урегулирования конфликта интересов. В первую очередь, это повышение уровня прозрачности и подотчётности работы должностных лиц. Здесь подразумевается возможность граждан свободно наблюдать и проводить мониторинг принятых учреждением решений. Граждане Латвии имеют свободный доступ к информации о принятых решениях государственным органом, регулярно обнародуются результаты и деятельность государственных органов в СМИ, в сети Интернет, в помещениях, где работают должностные лица, предоставляется возможность гражданам присутствовать на заседаниях (консультативных советах) органов власти.

Таким образом гражданский контроль может выявить потенциальный конфликт интересов путём анализа выше перечисленной информации и мониторинга деклараций об имуществе должностных лиц. Такой анализ может выявить сведения об экономической деятельности близких родственников должностного лица и информацию о правомерности такой деятельности через анализ официальных документов, где содержатся сведения о той или иной экономической деятельности и о принятых решениях. В результате гражданский контроль делает информацию о работе государственных органов прозрачной и доступной, что также повышает уровень подотчётности должностных лиц перед обществом. 
В Латвии общественный контроль как механизм противодействия коррупции прежде всего в сфере государственного управления включает в себя последовательность определённых действий, осуществляемых гражданами с целью предотвращения возможностей возникновения ситуации конфликта интересов. Данный контроль реализовывается через такие формы как: общественные обсуждения, общественные слушания, общественные проверки и общественный мониторинг.

Общественные слушания заключаются в реализации прав граждан Латвии на участие в процессе принятия решений органами государственной власти, органами местного самоуправления посредством проведения собрания для публичного обсуждения проектов указанных решений, а также действующих нормативных правовых актов по вопросу их соответствия общественным интересам. ${ }^{15}$

Общество Латвии также привлекается к общественному обсуждению социально значимых проектов, с целью выявления общественного мнения, учёта предложений и замечаний различных социальных групп, а также минимизации каких-либо частных интересов.

\subsection{3. Общественные приёмные}

Немало важным фактором вовлечения общества в предотвращение конфликта интересов является наличие функционирующих общественных приёмных. Суть таких общественных приёмных в предотвращении конфликта интересов заключается в распространении информации о фактах коррупции, в антикоррупционном просвещении граждан, в составлении запросов в органы государственной власти.

Например, в Латвии существует аналог общественной антикоррупционной приёмной на базе филиала международной организации Transperency International, куда гражданин может обратиться в случае вымогательства с него взятки или иных поборов. Подобную информацию граждане не всегда передают в правоохранительные органы, поскольку боятся ответственности за дачу взятки или другие последствия. На основе информации, полученной из так называемой антикоррупционной приёмной, возможно проведение общественного расследования или в крайнем случае обобщение обращений граждан по деятельности какого-либо должностного лица и передача этой обобщённой информации в компетентные органы для осуществления дальнейшей проверки.

Для достижения максимального результата по вовлечению граждан

15 Часть 1 Статья 5 конвенции ООН против коррупции - каждое государство-участник ... разрабатывает и осуществляет или проводит эффективную и скоординированную политику противодействия коррупиии, способствуюшую участию общества и отражаютую принципь ... честности и неподкупности, прозрачности и ответственности. 
в деятельность по предотвращению коррупции и конфликта интересов на официальных сайтах государственных органов и органов местного самоуправления Латвии в период с 2012 по 2016 год размещались банеры с прямым выходом на контактную информацию антикоррупционного бюро. В сети Интернет, а также в социальных сетях, на сайтах электронных и печатных СМИ в виде брошюры (памятки), а также в бумажном виде в помещениях государственных органов и органов местного самоуправления в тот же период времени регулярно размещалась информация о значимости обращений (сигнала) граждан о коррупционных действиях должностных лиц или нахождении их в ситуации конфликта интересов.

Начиная с 2013 года создана и функционирует обратная связь с обществом. В сети Интернет размещаются по просьбе заявителя сведения о результатах рассмотрения конкретных обращений граждан и организаций, а также анализ поступивших обращений граждан и организаций с информацией о фактах проявления конфликта интересов либо анализ причин отсутствия такового. Также законодательно с 2013 года в Латвии закреплено обязательное требование придавать огласке все коррупционные правонарушения связанные с нахождением должностного лица в ситуации конфликта интересов или нарушившего нормативными актами определённые ограничения и запреты для должностных лиц ${ }^{16}$.

\subsection{4. Общественный мониторинг}

Действенным механизмом общественного контроля над государством является общественный мониторинг. Он является комплексом мероприятий, которые регулярно должны проводиться с целью посредством опроса общества выявить в том числе и уровень восприятия коррумпированности различных государственных органов. Данный мониторинг населения призван решить две взаимосвязанные задачи:

1) предоставить объективную картину эффективности реализуемых антикоррупционных мероприятий;

2) получить объективную оценку состояния, форм и видов коррупционных проявлений (в т.ч. случаев конфликта интересов) в определённых сферах и областях государственного сектора.

Результаты такого мониторинга позволяют проводить своевременные консультации и готовить рекомендации по активизации органом государственной власти, органом местного самоуправления антикоррупционной политики своих

\footnotetext{
16 Часть 5 Статья 31 закона «О предотвращении конфликта интересов в деятельности государственных должностных лиц»-информация о нарушениях должностных лии помещается на своей домашней странице в Интернете после того, как вступило в силу .... Эта информация соответствующей структуры доступна на домашней странице в Интернете не более одного года со дня исполнения соответствующего решения (постановления).
} 
усилий в той или иной сфере, в т.ч. по предотвращению конфликта интересов.

В Латвии общественный мониторинг проводился регулярно лишь в период времени с 2012 по 2016 год. В данный период времени в ходе проведения общественного мониторинга в Латвии предлагались типовые обобщённые группы постоянных показателей для временной оценки результативности принимаемых органом государственной власти, органом местного самоуправления мер, направленных на профилактику коррупционных проявлений, в т.ч. и предотвращения конфликта интересов.

По результатам общественного мониторинга антикоррупционное бюро Латвии в период проведения общественного мониторинга инициировала проведение общественных обсуждений, общественных (публичных) слушаний, общественной проверки, изменения и уточнения антикоррупционной политики государства, а также проведения антикоррупционного просвещения определённых групп общества.

\subsection{5. Антикоррупционное просвещение}

Отсутствие у значительной части населения страны самых общих правовых представлений, незнание им своих прав и возможностей в противодействии коррупции и понимании что из себя представляет конфликт интересов - все это определяет необходимость осуществления целого комплекса мер по воспитанию антикоррупционного мировоззрения у общества. В период с 2012 по 2016 год данная деятельность была особенно заметна и находилась в приоритете деятельности антикоррупционного бюро Латвии, а именно:

1) активно велась просветительская работа в обществе по вопросам противодействия коррупции в любых её проявлениях (в т.ч. конфликта интересов); ${ }^{17}$

2) была поставлена цель сформировать устойчивое антикоррупционное мировоззрение у населения Латвии, а также повысить уровень правосознания и правовой культуры граждан.

Работа в упомянутый период времени по антикоррупционному просвещению сочеталась как непосредственно с отдельными категориями граждан, так и с опосредованными формами взаимодействия. При работе по антикоррупционному просвещению с отдельными категориями граждан непосредственно значительное внимание уделялось используемым формам просветительской деятельности:

1) для школьников и студентов предпочитались игровые формы просвещения (конкурсы, дискуссии, викторины);

\footnotetext{
17 Часть 1с Статья 13 конвенции ООН против коррупции - государство-участник принимает надлежащие меры ... проведение мероприятий по информированию населения, способствующих созданию атмосферы нетерпимости в отношении коррупиии, а также осуществление программ публичного образования, включая учебные программы в школах и университетах
} 
2) для граждан среднего возраста - интерактивные мультимедийные формы;

3) для лиц старшего поколения - наглядные формы с использованием раздаточного материала.

По вопросам повышения уровня правосознания граждан и популяризации антикоррупционных стандартов поведения на практике в этот период времент особенно активно проводились следующие мероприятия:

1) семинары (лекиии, тренинги и т.д.) по вопросам создания единого антикоррупционного стандарта поведения как граждан, так и должностных лиц;

2) семинары (круглые столь, выставки, общественно-экспертные совещания u m.д.) на антикоррупционные темы в сфере закупок товаров, работ, услуг для обеспечения государственных и муниципальных нужд;

3) Форумы (соииальные кампании, конференции и т.д.) на темы формирования антикоррупционного правосознания и нетерпимости к коррупционным деяниям среди должностных лиц, предпринимателей и других групп общества;

4) разрабатывались памятки, брошюры, плакаты для граждан, где были изложены факты о коррупции, положения отдельных правовых актов, меры ответственности, предусмотренные законодательством за коррупционные правонарушения, а также призывы не совершать коррупционных деяний и сообщать о таких в компетентные органы Латвии.

\subsection{6. Роль Интернета и блогосферы}

В современном мире возрастает роль Интернета и блогосферы. При существенном росте уровня общественного недовольства коррупцией (в т.ч. конфликта интересов) это может содержать в себе серьёзные социальные риски. Положительная роль Интернета и блогосферы выражается, безусловно, в том, что появляется возможность привлекать к широкому общественному обсуждению этой актуальной проблемы массы людей. Не стал исключением и Интернет для антикоррупционного бюро Латвии как один из инструментов проведения антикоррупционной политики. Созданные антикоррупционным бюро Латвии в 2015 году Интернет порталы «Draugiem.lv», «Facebook», «Twiter» и «odnoklassniki.ru» позволили Бюро начать решать антикоррупционные задачи в сфере антикоррупционного просвещения среди разных слоёв населения, реагировать на информацию в социальных сетях о фактах коррупции и конфликта интересов, а также шагать в ногу со временем и быть социально активными и разговаривать не только на одном языке с обществом, но и на одной социальной платформе. По мнению автора в данный период времени роль Интернета и блогосферы не до конца оценена антикоррупционным бюро Латвии, в связи с чем и не использована в полной мере в активном вовлечении общества в предотвращение конфликта интересов должностных лиц. 


\section{3. Выводы и предложения}

Таблица № 6

Изменения индекса восприятия коррупции для Латвии

\begin{tabular}{|c|c|c|c|}
\hline & места & & пункты \\
\hline 2016 & 44 & $+\mathbf{1 7}$ & 57 \\
\hline 2015 & 40 & & 55 \\
\hline 2014 & 43 & & 55 \\
\hline 2013 & 49 & & 53 \\
\hline 2012 & 54 & & 49 \\
\hline 2011 & 61 & & 42 \\
\hline
\end{tabular}

Антикоррупционная политика по вовлечению общества в процесс предотвращения коррупции и конфликта интересов регламентируется в Латвии с середины 90-х годов. Однако активная её практическая реализация приходится на период времени с 2011 по 2016 год. Сравнивая данный период времени с достигнутыми в это же время международными (см. Таблицу №6) и национальнымирезультатамипредотвращениякоррупции,необходимоотметить, что у Латвии наилучших результатов до и после данного периода времени не было. Конечно, предотвращение и борьба с коррупцией предусматривает системный подход, и участие (вовлечение) общества в этот процесс является лишь одним из инструментов. Однако по мнению автора этот инструмент очень важный и может быть наиболее эффективным в предотвращении коррупции и конфликта интересов. Значение данного инструмента нельзя не дооценивать и им пренебрегать. Как видно на практике, ослабив антикоррупционное просвещение и вовлечение общества в противодействие коррупции, ситуация меняется не в лучшую сторону. Общество становиться равнодушным к внутренним процессам государственного сектора, затем безучастным и в итоге даже оправдывает случаи коррупции. Поэтому, по мнению автора, активное вовлечения (даже соучастие) общества в процессы антикоррупционной политики даже не столь желательны, сколько необходимы, т.к. от степени вовлечения общества в антикоррупционную политику существенно зависят результаты по эффективному или неэффективному проведению антикоррупционной политики любого государства (как можно наблюдать на примере Латвии). Дополнительно автор отмечает, что системный подход к планированию вовлечения общества в предотвращение коррупции и конфликта интересов, может послужить ожидаемым результатом прогнозирования изменений оценки (снижения) коррупционных рисков в государственного секторе. 
Однако для данного результата автор предлагает создание условий для эффективного вовлечения общества в сферу противодействии коррупции и предотвращения конфликта интересов:

1. Оценить существующую эффективность вовлечения общества в процесс антикоррупционной политики, а также предотвращения коррупции и конфликта интересов, проведя социологические исследования в форме анкетирования граждан, с целью оценить, например:

1) состояния результативности предусмотренных законодательством механизмов антикоррупционного взаимодействия между государством и обществом;

2) качество информационного обмена и обратной связи общества и государства в вопросах предотвращения коррупции;

3) проблемы и востребованные аспекты участия общества в реализации антикоррупционных мер в конкретных сферах и др.

Рекомендуется создание социологического исследования на системной основе. Исследование должно проводиться не реже одного раза в год. Полученные материалы исследования должны быть приняты к сведению, а также, по возможности, учтены при реализации компетентными органами антикоррупционной политики.

2. Осуществление общественного антикоррупционного контроля за достоверностью сведений о доходах, об имуществе и обязательствах имущественного характера, представляемых должностными лицами.

3. Деятельность любого государственного органа должна быть прозрачной, что является залогом успеха в противодействии коррупции, предотвращения конфликта интересов и, в том числе, конструктивного взаимодействия с общественными организациями в сфере противодействия коррупции. С этой целью необходимо осуществление следующих действий по предоставлению на официальном сайте в сети Интернет государственными органами информации текстов нормативных правовых актов, отчётов, решений комиссий по соблюдению требований к служебному поведению и урегулированию конфликта интересов, результатов общественного контроля и содержания решений государственного органа, принятых по итогам рассмотрения таких результатов, результатов социологических исследований по выявлению коррупции и конфликта интересов, результатов анализа работы телефона доверия и др.

4. Проведение мероприятий с детьми, подростками, представителями студенческой среды, в целях повышения правовой культуры общества и антикоррупционного просвещения, формирования атмосферы нетерпимого отношения к коррупции и выработки антикоррупционного стандарта поведения, 
привития отношения к коррупции, как к угрозе безопасности и демократии.

5. Необходимо оценить и предусмотреть возможность использования следующих форм вовлечения общества в процесс предупреждение коррупции и конфликта интересов:

1) участие представителей общественности в работе аттестационных и конкурсных комиссий высших должностных лиц ${ }^{18}$;

2) участие общества в мероприятиях, направленных на противодействие коррупции, снижение административных барьеров, повышение качества государственного управления;

3) развитие инфраструктуры информационного обмена, каналов обратной связи между государственными органами, обществом и гражданами;

4) заключение соглашений о взаимодействии в сфере противодействия коррупцииипредотвращенияконфликтаинтересовмеждугосударственными органами и общественными организациями, определяющих их взаимные обязательства в сфере противодействия коррупции и предотвращения конфликта интересов; участие в обеспечении контроля за их реализацией; участие в проведении анализа результативности заключённых соглашений;

5) организация и проведении открытых и публичных лекций, научнопрактических и учебных семинаров, круглых столов, и других мероприятий с целью разъяснения антикоррупционной политики и деятельности;

6) сбор и проведении квалифицированной юридической оценки информации, поступающей от граждан о коррупционных схемах, фактах коррупционного поведения, об очевидном несоответствии расходов должностных лиц их официальным доходам, а также нахождении должностного лица в ситуации конфликта интересов;

7) выявление информации о проблемах, с которыми сталкиваются граждане и общество в целом, активно занимающиеся предотвращением коррупции и конфликта интересов;

8) распространение позитивного опыта противостояния гражданами попыткам коррупционного давления и вовлечения их в коррупционную деятельность;

9) издание информационных материалов, брошюр, буклетов и т.д. для различных групп общества, по различным аспектам противодействия коррупции.

\footnotetext{
18 Часть 3 Статья 4 закона о Бюро по предотвращению и борьбе с коррупцией - отбор претендентов на должность начальника Бюро осуществляет комиссия, которой руководит директор Государственной канцелярии. ... В отборе претендентов на должность начальника Бюро на правах советчиков принимают участие не более трех уполномоченных представителей Обиественно-консультативного совета
} 


\section{Использованная литература и источники}

1. Охотский Е.; Шедий М.; Охотский И.; Левакин И., Противодействие коррупции, Юрайт, Москва, 2018, стр. 427

2. Конвенция Организации Объединенных Наций против коррупции, принята резолюцией 58/4 Генеральной Ассамблеи от 31 октября 2003 года

3. Международный кодекс поведения государственных должностных лиц, принят резолюцией 51/59 Генеральной Ассамблеи ООН от 12 декабря 1996 года

4. Закон о Бюро по предотвращению и борьбе с коррупцией, принят в Сейме 18 апреля 2002 года, Latvijas Vēstnesis, 65, 30.04.2002

5. Закон о предотвращении конфликта интересов в деятельности государственных должностных лиц, принят в Сейме 25 апреля 2002 года, Latvijas Vēstnesis, 69, 09.05.2002

6. ОЭСР, Декларации активов для государственных служащих, OECD.org, https://www.oecd.org/daf/anti-bribery/48973261.pdf, доступ 2 июня 2020 года

7. ОЭСР, Антикоррупционные реформы в Кыргызстане. 4-й раунд мониторинга в рамках Стамбульского плана действий по борьбе с коррупцией, OECD.org, https://www.oecd.org/corruption/acn/OECD-ACNKyrgyzstan-4th-Round-Monitoring-Report-2018-RUS.pdf, доступен на 29 мая 2020 года

8. OECD, Managing Conflict of Interests in the Public Sector. Guidelines, OECD. org, https:/www.oecd.org/gov/ethics/49107986.pdf, доступен на 30 мая 2020 года

9. Юридический консультант, Конфликт интересов на гражданской службе, JK.ru http://www.jk.ru/analiticheskaja-informatsija/konflikt-interesov/, доступ 30 мая 2020 года

10. Baltic News Network, Delna: Латвии не хватает мер по борьбе с коррупцией, bnn-news.ru, https://bnn-news.ru/i-delna-i-latvii-ne-hvataet-mer-po-borbe-skorrupcziej-226761, доступ 1 июня 2020 года

11. Редакция Латвийского общественного СМИ, Латвия теряет позиции в Индексе восприятия коррупции, Rus.lsm.lv,https://rus.lsm.lv/statja/novosti/ obschestvo/latvija-terjaet-pozicii-v-indekse-vosprijatija-korrupcii.a345787/, доступ 1 июня 2020 года

12. НовостиООН,Врезультатекоррупциимироваяэкономикакаждыйгодтеряет 2,6 трлн долларов, UN.org, https://news.un.org/ru/story/2018/12/1344641, доступен на 19 мая 2020 года

13. Портал Бюро по предотвращению и борьбе с коррупцией Латвии - https:// www.knab.gov.lv

14. Портал Службы государственных доходов Латвии - https:/www.vid.gov.lv

15. Портал Transparency International - https://www.transparency.org/en 